\title{
Plasmid Curing of Escherichia coli Cells with Ethidium Bromide, Sodium Dodecyl Sulfate and Acridine Orange
}

\author{
MA Zaman, MH Pasha and MZ Akhter* \\ Department of Microbiology, university of Dhaka, Dhaka-1000, Bangladesh
}

(Received 26 May 2010; Accepted 21 August 2010)

\begin{abstract}
The plasmid eliminating abilities of acridine orange, ethidium bromide and sodium dodecyl sulfate were investigated on multi drug resistant Escherichia coli from urinary tract infection specimens. Three different concentrations of each curing agent (Et-Br, SDS and AO) were used. The frequencies of cured cells were $5.55 \%$ (with $50 \mu \mathrm{g} / \mathrm{ml}$ ) and $11.76 \%$ (with $75 \mu \mathrm{g} / \mathrm{ml}$ ) for acridine orange, $14.29 \%$ (with $100 \mu \mathrm{g} / \mathrm{ml}$ ), $21.05 \%$ (with $100 \mu \mathrm{g} /$ $\mathrm{ml}$ ), $17.65 \%$ (with $125 \mu \mathrm{g} / \mathrm{ml}$ ) for ethidium bromide and $7.4 \%$ (with $10 \%$ w/v) \& $6.67 \%$ (with $10 \%$ w/v) for sodium dodecyl sulfate. However, no cured cells were obtained from $100 \mu \mathrm{g} / \mathrm{ml}$ acridine orange, $75 \mu \mathrm{gg} / \mathrm{ml}$ ethidium bromide and 8 and $12 \%$ SDS. Analysis of profiles of wild type and plasmid cured strains by electrophoresis yielded bands of varying sizes for wild type cells, but none were obtained for Et-Br cured cells. Acridine orange treated cells could eliminate only plasmids of 2.7 MDa and another smaller than 2 MDa.
\end{abstract}

Key Words: Plasmid curing, Escherichia coli, Ethidium Bromide, Sodium Dodecyl Sulfate, Acridine Orange.

\section{Introduction}

Plasmid is one of the several environmental and genetic factors that carry the resistance property against a specific drug or a number of drugs in bacteria ${ }^{1}$. R-plasmids from resistant strains of an organism may transfer to a sensitive counterpart that would in due course show the same drug resistance as the donor strain². Plasmids can also be eliminated by curing agents which can be used to display the role of R-plasmid in drug resistance. The techniques used to promote curing include exposing the host strain to elevated temperatures, use of chemical agents such as intercalating dyes (acridine orange, ethidium bromide), treatment with crystal violet, sodium dodecyl sulfate (SDS), thymidine starvation and exposure to UV radiation ${ }^{1}$. Different plasmids vary considerably in their property to be cured, and not necessarily depending upon properties of specific plasmid.

When working with some plasmid-containing bacteria, it is often desirable to obtain a plasmid-cured derivative, allowing a direct comparison to be made between the plasmid-containing and plasmid-cured cells. Some plasmids undergo spontaneous segregation and deletion, but the majority is extremely stable and requires the use of curing agents or other procedures to increase the frequency of spontaneous segregation. The usefulness of curing agents is unpredictable in many bacterial strains, as there are no standard protocols applicable to all plasmids ${ }^{3}$. As no universally effective curing agent has yet been identified, curing experiments are generally conducted on trial and error basis, both with respect to the choice of the curing agent and the culturing conditions used. Some curing agents work in a non-specific way by damaging and stressing out the cells, while some seem to act much selectively ${ }^{4}$. The present study is a preliminary effort to observe the curing efficiencies of acridine orange, ethidium bromide and sodium dodecyl sulphate on multi-drug resistant Escherichia coli cells, and also to establish a correlation between plasmid elimination and subsequent loss of drug resistance to determine the involvement of R-plasmids in drug resistance of these strains.

\section{Materials and Methods}

\section{Sample collection}

Ten clinical isolates of Multi Drug Resistant (MDR) E. coli from UTI patients were collected from a local diagnostic centre of Dhaka, Bangladesh.

\section{Antibiotic sensitivity assay of bacterial isolates}

Bacterial susceptibilities to antimicrobial agents were determined in vitro by using the Kirby Bauer standardized agar disc-diffusion method $^{5}$. Antibiotic discs of ampicillin (10 $\mu$ g), amoxicillin (30 $\left.\mu \mathrm{g}\right)$, cloxacillin (5 $\mu \mathrm{g})$, ceftazidime (30 $\mu \mathrm{g})$, ceftriaxon (30 $\mu \mathrm{g})$, cephalexine (30 $\mu \mathrm{g})$, gentamicin $(10 \mu \mathrm{g})$, imipenem (10 $\mu \mathrm{g})$, nitrofurantoin (10 $\mu \mathrm{g})$ and tetracyclin $(30 \mu \mathrm{g})$ were used.

\section{Isolation of plasmid DNA}

Plasmid isolation was performed using the alkaline lysis method described by Birnboim and Doly ${ }^{6}$. After isolation of plasmid DNA a horizontal agarose gel electrophoresis was carried out, and the method followed was as described by Meyers et al. ${ }^{7}$. E. coli PDK-9 strain was used as the DNA molecular weight marker.

\section{Curing of plasmids}

Curing of plasmids was performed by the method of Tomoeda $e t$ $a l .{ }^{8}$. Three types of curing agents, each with 3 different 
concentrations [ethidium bromide $(75 \mu \mathrm{g} / \mathrm{ml}, 100 \mu \mathrm{g} / \mathrm{ml}$ and 125 $\mu \mathrm{g} / \mathrm{ml})$, acridine orange $(50 \mu \mathrm{g} / \mathrm{ml}, 75 \mu \mathrm{g} / \mathrm{ml}, 100 \mu \mathrm{g} / \mathrm{ml})$, sodium dodecyl sulphate (8\%, $10 \%, 12 \%)]$ were used to cure the plasmids. Amoxicillin resistance was used as the selectable marker.

Four isolates were selected randomly for plasmid curing which were E. coli 212587, E. coli 212973, E. coli 208366 and E. coli 207940. An overnight culture of each test organism in Luria Broth (LB) containing amoxicillin was diluted to $10^{4}$ cells/ml using freshly prepared sterile LB by serial dilution technique. From this diluted culture, $0.5 \mathrm{ml}$ was added with $4.5 \mathrm{ml} \mathrm{LB}$ containing different concentrations of curing agents. Thus, the concentration became $10^{3}$ cells $/ \mathrm{ml}$. The cultures were then incubated at $37^{\circ} \mathrm{C}$ in an orbital shaker at $150 \mathrm{rpm}$ for 48 hours. After incubation, the broth culture was again diluted to $10^{3}$ cells/ml with sterile normal saline. Ten $\mathrm{ml}$ of the culture was spread on Luria Agar medium. After a 24-hour incubation at $37^{\circ} \mathrm{C}$, the plates were observed for growth. From this plate culture, some well-isolated colonies were randomly selected and simultaneously patched with sterile toothpick on one Luria Agar medium without antibiotic and another Luria Agar containing amoxicillin (25 mg/ml), with a numbered grid line attached on the bottom of each plate. After 24-hour incubation at $37^{\circ} \mathrm{C}$, plates were observed for the cured cells. The cured plasmid cells were detected comparing the development of bacterial colonies on antibiotic containing plate with that of the normal (without antibiotic) plate. The samples that showed colonies on normal LB agar but failed to grow on LB agar supplemented with amoxicillin were the possible cured isolates.

\section{Results and Discussion}

Cured cells were achieved with $100 \mu \mathrm{g} / \mathrm{ml}$ and $125 \mu \mathrm{g} / \mathrm{ml}$ ethidium bromide (Table 1), $10 \%$ (w/v) SDS (Table 2) and $50 \mu \mathrm{g} / \mathrm{ml}$ and $75 \mu \mathrm{g} /$ $\mathrm{ml}$ acridine orange (Table 3 ) although the frequencies of cured colonies were quite low. The results from Table 1-3 show that amongst the three curing agents, ethidium bromide was able to cure plasmids successfully at a higher rate than the other two agents. The frequencies of cured cells were $5.55 \%$ (with $50 \mu \mathrm{g} / \mathrm{ml}$ ) and $11.76 \%$ (with $75 \mu \mathrm{g} / \mathrm{ml}$ ) for acridine orange, $21.05 \%$ (with $100 \mu \mathrm{g}$ / $\mathrm{ml}$ ), $17.65 \%$ (with $125 \mu \mathrm{g} / \mathrm{ml}$ ) for ethidium bromide and $7.4 \%$ (with $10 \% \mathrm{w} / \mathrm{v}$ ) and $6.67 \%$ (with $10 \% \mathrm{w} / \mathrm{v}$ ) for sodium dodecyl sulfate. On the other hand, no cured cells were obtained from $100 \mu \mathrm{g} / \mathrm{ml}$ acridine orange, $75 \mu \mathrm{g} / \mathrm{ml}$ ethidium bromide and 8 and $12 \%$ SDS.

Table 1. Curing frequencies by treatment with various concentrations of Ethidium Bromide (EtBr)

\begin{tabular}{|c|c|c|c|c|c|}
\hline $\begin{array}{l}\text { E. coli } \\
\text { isolates }\end{array}$ & $\begin{array}{l}\text { Inoculum size } \\
\text { (cells/ml) } \times 10^{4}\end{array}$ & $\begin{array}{l}\text { EtBr conc. } \\
(\mu \mathrm{g} / \mathrm{ml})\end{array}$ & $\begin{array}{c}\text { Time of incubation } \\
\text { (hour) }\end{array}$ & $\begin{array}{l}\text { No. of cured colonies / } \\
\text { no. of total colonies in } \\
\text { Amoxicillin-Luria agar plate }\end{array}$ & $\begin{array}{l}\text { Frequency of } \\
\text { cured } \\
\text { colonies (\%) } \\
\end{array}$ \\
\hline E. coli 212587 & 1.7 & 100 & 48 & 0 & 0 \\
\hline E. coli 212587 & 0.9 & 125 & 48 & 0 & 0 \\
\hline E. coli 212973 & 1.15 & 75 & 48 & 0 & 0 \\
\hline E. coli 212973 & 0.95 & 125 & 48 & 0 & 0 \\
\hline E. coli 208366 & 1.05 & 75 & 48 & 0 & 0 \\
\hline E. coli 208366 & 0.85 & 100 & 48 & 0 & 0 \\
\hline E. coli 208366 & 0.79 & 125 & 48 & $3 / 17$ & 17.65 \\
\hline E. coli 207940 & 0.98 & 75 & 48 & 0 & 0 \\
\hline
\end{tabular}

Table 2. Curing frequencies by treatment with various concentrations of sodium dodecyl sulfate (SDS)

\begin{tabular}{|c|c|c|c|c|c|}
\hline $\begin{array}{l}\text { E. coli } \\
\text { isolates }\end{array}$ & $\begin{array}{l}\text { Inoculum size } \\
\text { (cells/ml) } \times 10^{4}\end{array}$ & $\begin{array}{l}\text { SDS conc. } \\
(\mathrm{w} / \mathrm{v}) \%\end{array}$ & $\begin{array}{l}\text { Time ofincubation } \\
\text { (hour) }\end{array}$ & $\begin{array}{c}\text { No. of cured colonies / } \\
\text { no. of total colonies in } \\
\text { Amoxicillin-Luria agar plate }\end{array}$ & $\begin{array}{l}\text { Frequency of } \\
\text { cured } \\
\text { colonies (\%) }\end{array}$ \\
\hline E. coli 212587 & 1.7 & 10 & 48 & $2 / 27$ & 7.4 \\
\hline E. coli 212587 & 0.9 & 12 & 48 & 0 & 0 \\
\hline E. coli 212973 & 1.15 & 8 & 48 & 0 & 0 \\
\hline E. coli 212973 & 0.95 & 12 & 48 & 0 & 0 \\
\hline E. coli 208366 & 1.05 & 8 & 48 & 0 & 0 \\
\hline E. coli 208366 & 0.85 & 10 & 48 & $1 / 15$ & 6.67 \\
\hline E. coli 208366 & 0.79 & 12 & 48 & 0 & 0 \\
\hline E. coli 207940 & 0.98 & 8 & 48 & 0 & 0 \\
\hline
\end{tabular}


Table 3. Curing frequencies by treatment with various concentrations of acridine orange

\begin{tabular}{lccccc}
\hline $\begin{array}{l}\text { E. coli } \\
\text { isolates }\end{array}$ & $\begin{array}{c}\text { Inoculum size } \\
\left(\text { cells/ml) } \times 10^{4}\right.\end{array}$ & $\begin{array}{c}\text { AO conc. } \\
(\mu \mathrm{g} / \mathrm{ml})\end{array}$ & $\begin{array}{c}\text { Time of incubation } \\
\text { (hour) }\end{array}$ & $\begin{array}{c}\text { No. of cured colonies / } \\
\text { no. of total colonies in } \\
\text { Amoxicillin-Luria agar plate }\end{array}$ & $\begin{array}{c}\text { Frequency of } \\
\text { cured } \\
\text { colonies (\%) }\end{array}$ \\
\hline E. coli 212587 & 1.3 & 50 & 48 & 0 & 0 \\
E. coli 212587 & 1.7 & 75 & 48 & $2 / 17$ & 11.76 \\
E. coli 212587 & 0.9 & 100 & 48 & 0 & 0 \\
E. coli 212973 & 1.15 & 50 & 48 & $1 / 18$ & 5.55 \\
E. coli 212973 & 1.4 & 75 & 48 & 0 & 0 \\
E. coli 212973 & 0.95 & 100 & 48 & 0 & 0 \\
E. coli 208366 & 1.05 & 50 & 48 & 0 & 0 \\
E. coli 208366 & 0.85 & 100 & 48 & 0 & 0 \\
E. coli 208366 & 0.79 & 50 & 48 & 0 & 0 \\
E. coli 207940 & 0.98 & 75 & 48 & 0 & 0 \\
E. coli 207940 & 1.12 & 100 & 48 & 0 & 0 \\
E. coli 207940 & 0.92 & & & 0 & 0 \\
\hline
\end{tabular}

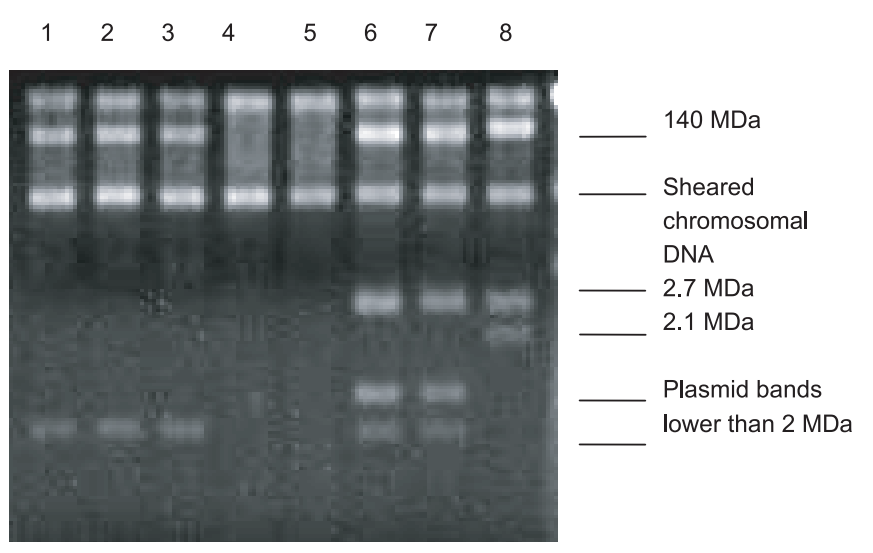

Figure 1. Plasmid profiles of cured and wild type cells. Lane 1, 2, 3 - E.coli 212587 cured by acridine orange ( $75 \mu \mathrm{g} / \mathrm{ml})$, Lane 4, 5 - E. coli 208366 cured by ethidium bromide (125 $\mu \mathrm{g} / \mathrm{ml})$, Lane 6 - original E. coli 212587, Lane 7- original E. coli 208366 and Lane 8- E. coli PDK-9 marker.

Wild type cells contained plasmid bands of various sizes; a band slightly less than $140 \mathrm{MDa}$, one band at 2.7 MDa and two bands smaller than 2 MDa. Agarose gel electrophoresis of the cured colonies revealed that the cells treated with ethidium bromide were able to eliminate all the plasmid bands. However, acridine orange treated cells could eliminate 2.7 MDa and another plasmid that was smaller than $2 \mathrm{MDa}$ (Figure 1). The cured colonies also lost the amoxicillin resistance. In case of ethidium bromide, the loss of the large plasmid can be correlated with the concommitant loss of amoxicillin resistance. However, although acridine orange could not eliminate the largest plasmid, it still showed the loss of amoxicillin resistance. It can be suggested that acridine orange might have disrupted or changed the larger plasmid in such a way that its amoxicillin resistance gene could not function. Otherwise, the resistance might be borne on the smaller plasmids. Further investigations are necessary to confirm this.
The effectiveness of curing methods depends on the nature of the bacterial host and/or plasmids where some may work better than the others ${ }^{9}$. The plasmid curing of Escherichia coli and other bacteria have been previously reported. Several have used ethidium bromide, sodium dodecyl sulfate and acridine orange. A plasmid-containing wild-type E. coli strain was treated with sodium dodecyl sulfate and ethidium bromide. Plasmid loss in cured $E$. coli cells resulted in the disappearance of the outer membrane components and a concomitant change in the thickness of the peptidoglycan layer ${ }^{10}$. A rapid, simple, and effective method for curing of a wide range of Escherichia coli antibiotic resistance plasmids has been previously described ${ }^{11}$, and this involved treatment with acridine orange followed by growth in sub-lethal concentration of antibiotics and penicillin selection. Such bacteriostatic conditions resulted in a curing efficiency of more than $98 \%$ in all cases tested. Chin et al. subjected five Lactobacillus strains with plasmid curing agents, such as novobiocin, acriflavin, SDS, and ethidium bromide. In no cases did the antibiotic resistance of these strains proved to be curable, with the exception of the erythromycin resistance ${ }^{12}$.

\section{Conclusion}

UTI can be caused by a wide variety of microbes with uropathogenic E. coli as the major culprit. They cause this disease either by chromosome mediated or by plasmid mediated mechanism. Plasmid mediated resistance that can be transferred between cells enable rapid spread of the disease. The present study investigated the efficiencies of different curing agents on the $E$. coli isolates from UTI specimen. For this purpose, three different types of curing agents were used and the results obtained was a preliminary indication of association of drug resistance of the clinical isolates of $E$. coli with plasmids. Among the three curing agents used, ethidium bromide displayed greater success rate than the rest. 


\section{References}

1. Clowers RC. 1972. Molecular structure of bacterial plasmids. Bacterial Rev. 36: 361-405.

2. Datta N and Hedges ILW. 1972. Host range of R factors. J. Gen. Microbiol.70: 453.

3. Trevors JT. 1985. Plasmid curing in bacteria. FEMS Microbiology Letters. 32(3-4): 149-157.

4. Hohn B and Korn D. 1969. Co-segregation of a sex factor with the Escherichia coli chromosome during curing by acridine orange. Journal of Molecular Biology. 45: 385-395.

5. Bauer AW, Kirby WMM, Sherris, JC and Turck M. 1996. Antibiotic susceptibility testing by a standard disc method. Amer. J. Cln. Pathol. 45: 494496.

6. Birnboim H and Doly J. 1979. A rapid alkaline extraction procedure for screening recombinant plasmid DNA. Nucleic Acids Res. 7: 1513-1523.
7. Meyers JA, Sanchez D, Elwell LP and Falkow S. 1976. Simple agarose gel electrophoresis method for the identification and characterization of plasmid deoxyribonuclic acid. J. Bactoriol. 127: 152937.

8. Tomoeda M, Inuzuka M, Kubo N and Nakamura S. 1968. Effective elimination of drug resistance and sex factors in Escherichia coli by sodium dodecyl sulfate. J. Bacteriol. 95:1078-1089.

9. Ghosh S, Mahapatra NR, Ramamurthy T and Banerjee PC. 2000. Plasmid curing from an acidophilic bacterium of the genus Acidocella. FEMS Microbiol. Lett. 183: 271-274.

10. Rosas SB, Calzolari A, Torre JL, Ghittoni NE and Vasquez C. 1983. Involvement of a Plasmid in Escherichia coli Envelope Alterations. Journal of Bacteriology. 155(1): 402-406.

11. Thomas JM and Kay WW. 1984. A simple and rapid method for the elimination of R plasmids from enteric bacteria. Current Microbiology. 11(3): 155-157.

12. Chin SC, Abdullah N, Siang TW and Wan HY. 2005. Plasmid Profiling and Curing of Lactobacillus Strains Isolated from the Gastrointestinal Tract of Chicken. The Journal of Microbiology. 43(3): 251-256 